\title{
KEMAJUAN BUDAYA MASYARAKAT MAKASSAR ABAD XVII
}

Oleh:

Susmihara

mihara.ogi@gmail.com

Lecturer of Adab and Humanities Fuculty of Alauddin State Islamic University of Makassar

\begin{abstract}
The plurality of social life of Makassar society in XVII century is a central point in the realization of gaining progress and performance in Makassar at the time. The plural life marked by principle of "high sea" and the tolerance among religious and the readiness Makassar government who politicized the society which has different background in mutual life.
\end{abstract}

Keywords: Plurality, tolerance, religious.

\section{A. Pendahuluan}

Di era sekarang ini ummat manusia diperhadapkan pada tantangan sebagaimana yang pernah terjadi di masa silam, seperti pluralisme agama, konflik intern agama dan konflik antar agama. Selama kurun waktu yang lama, interaksi ummat beragama banyak diwarnai oleh kecurigaan dan permusuhan, fenomena ini kelihatannya berlanjut sampai sekarang dengan berbagai kejadian-kejadian yang menarik perhatian dunia,

Olehnya itu menarik dikaji dengan pendekatan kesejarahan tentang kehidupan plural yang pernah terwujud di Makassar pada kurun waktu beberapa abad yang silam (Abad XVII). Makassar yang dijadikan batasan penulisan ini bukanlah merupakan wilayah kota yang kini dikenal dengan Kota Makassar. Makassar yang dimaksudkan sesungguhnya adalah Makassar tempo dulu sebagai wilayah pemukiman suku Makassar pada abad XVII yang dikenal dengan Kerajaan Makassar. Dalam sejarah Sulawesi Selatan daerah ini merupakan kerajaan terbesar di kawasan timur Indonesia masa lalu yang dikenal dalam dunia pelayaran dan perdagangan.

Sumber lokal mengenai awal munculnya kerajaan ini pada masa pemerintahan Tumanurung, sangat sedikit yang dapat diketahui sebab keterangan-keterangan hanya berdasar pada ingatan yang masih tersimpan oleh generasi berikutnya dari kebiasaan menuturkan riwayat masa lalu. Catatan ringkas barulah dapat ditemukan dalam lontara bilang yang berawal ditulis pada masa pemerintahan raja Gowa ke IX. Dari catatan itu diketahui bahwa menjelang abad ke XIV, pada masa pemerintahan raja Gowa ke VI Tunatangka Lopi membagi wilayah kerajaan Gowa kepada dua putranya yaitu Batara Gowa berkuasa di Gowa sebagai raja Gowa ke VIII sedang Karaeng Loe ri Se'ro mendirikan kerajaan baru yang bernama kerajaan Tallo. Pada masa pemerintahan raja Gowa ke IX Daeng Matanre Karaeng Manguntungi Tumaparisi' 
Kallonna, baginda memerangi kerajaan kembarnya sendiri, namun setelah terjadi perdamaian, maka keduanya mengadakan ikrar bersama bahwa ia-namo ampasewai Gowa-Tallo ia namo nacalla Dewata = Barang siapa mengadu domba Gowa-Tallo dialah yang dikutuk Dewata. Ketika itu kehidupan masyarakat dinyatakan dengan rua Karaeng se re ata $=$ Dua raja atas satu rakyat. Sejak kedua kerajaan tersebut menyepakati perjanjian ini, maka siapa yang menjabat raja Gowa dia adalah raja kerajaan Gowa-Tallo dan Raja Tallo sekaligus menjabat mangkubumi kerajaan Gowa. Para Sejarawan kemudian menamakan kerajaan kembar ini dengan "Kerajaan Makassar"

Letak kerajaan Makassar sangat strategi ia berada di sepanjang pesisir pantai selatan Sulawesi Selatan yang diapit oleh dua muara sungai yakni sungai Je'neberang dan sungai Tallo. Sungai ini berfungsi sebagai jalur lalu lintas penduduk yang hendak berhubungan dengan dunia luar dan menjadikan Makassar sebagai pangkalan niaga. Sekalipun pada mulanya Makassar hanya merupakan bandar transito dari lalu lintas perdagangan rempah-rempah antara Malulu dan Malaka, namun pada masa pemerintahan raja Gowa ke IX Tumaparisi kallonna (1510-1546) akhirnya berkembang menjadi Bandar niaga yang ramai. Pada saat itu raja telah menetapkan peraturan perang dalam rangka ekspansi dan pengangkatan berbagai aparatur pemerintahan, termasuk syahbandar yang mengurus bea cukai niaga kerajaan. Pada saat itu pula Malaka jatuh ke tangan Portugis pada tahun 1511, yang kemudian Makassar memperoleh kedudukan penting sebagai penghubung dengan negeri yang dikuasai Portugis.

Keunggulan kekuasaan dan keterlibatan Kerajaan Makassar dalam dunia perdagangan serta perkembangan kota Makassar sebagai pusat niaga, telah mengundan berbagai pihak untuk menjalin hubungan dagang sehingga Makassar telah menjadi bandar niaga yang terpenting. Bahkan pada masa pemerintahan raja Gowa ke $\mathrm{X}$ Tunipallangga Ulaweng atas izin beliau sehingga pedagang muslim dari kepulauan nusantara yakni pedagang pedagang Melayu, Patani, Johor, Campa, Minangkabau dan Jawa, menetap di Makassar. Menyusul pada periode selanjutnya adalah pedagangpedagang asing seperti India, Portugis, Arab dan Cina mulai berdatangan mencari tempat untuk kantor-kantor dan perwakilan dagangnya di sekitar Bandar Somba Opu Makassar.

Sekalipun pada masa pemerintahan raja Gowa XIII I Tepu Daeng Parabbung Tunipasulu keadaan Makassar sangat kacau akibat sikap sewenang-wenang raja dan mengakibatkan banyaknya migran lari dari Makassar dan sempat menimbulkan keresahan hati rakyat, namun keadaan tersebut sempat dipulihkan kembali oleh raja Gowa XIV I Mangarangi Daeng Manrabbia Sultan Alauddin yang didampingi oleh cendikiawan sekaligus negarawan mangkubumi kerajaan Gowa Tallo yakni I Malingkaang Daeng Manyonri Sultan Awalul Islam. Bahkan kemajuan Makassar pada masanya lebih pesat lagi karena tercatat banyak peristiwa penting yaitu diterimanya ajaran Islam menjadi agama kerajaan. Makassar juga ikut menjiwai perkembangan Nusantara dan awal terjadinya kontak dengan VOC

Kenyataan ini telah menuntut kebijakan Sutan Alauddin sebagai raja Gowa ke XIV dan Sultan Awalul Islam sebagai Mangkubuminya untuk menjadikan kerajaan Makassar sebagai kerajaan maritim di Nusantara. Menyikapi fenomena tersebut, 
beliau menjadikan kembali Kale Gowa sebagai pusat pemerintahan kerajaan sedangkan Somba Opu yang tadinya sebagai pusat pemerintahan sekaligus sebagai bandar Makassar, dijadikan sebagai kota raya yang melayani perniagaa dalam dan luar negeri.

Terkait dengan diterimanya Islam secara resmi menjadi agama kerajaan yang ditandai dengan shalat Jumat pertama pada 9 November 1607 bertepatan dengan 18 Rajab 1017, maka kedudukan Sultan Alauddin semakin kuat sebab selain pemimpin negara juga pemimpin agama Islam ( Amirul Mukminin). Sejak itu satu demi satu kerajaan di Sulawesi Selatan dirangkul, dan setelah rajanya menerima Islam kemudian disusul oleh masyarakat. Kebijakan Sultan terhadap pemeluk agama non Islam adalah di samping memberi kebebasan melaksanakan aktifitasnya untuk mencari nafkah, juga diberi kebebasan melaksanakan upacara keagamaan sesuai dengan keyakinan mereka.

Sejak adanya prinsip dan sikap hidup tersebut sebagai hasil transformasi nilai Islam, Maka pengertian pluralisme muncul di Makassar dan praktek nilai-nilai toleransi sebagai aplikasi dari kehidupan pluralistik berlangsung dengan lancar antara suku, etnis, muslim dan non muslim. Demikian pula suku bangsa dari luar termasuk Eropah, diberi kesempatan untuk bermukim di sekitar bandar Somba Opu Makassar. Keterbukaan dengan bangsa lain diwujudkan dengan jalinan hubungan dagang dengan prinsip tidak ada monopoli perdagangan.

Nilai-nilai solidaritas inilah seharusnya dipelihara dalam kehidupan berbangsa dan bernegara demi terwujudnya kedamaian dan ketenteraman dalam hidup bermasyarakat. Bukan sebaliknya yang tampak pada dekade terakhir ini dimana-mana terjadi konflik antar ummat beragama yang pada akhirnya tidak memberi jaminan keamanan dalam kehidupan masyarakat. Terlebih lagi saat sekarang ini di mana bangsa Indonesia diperhadapkan pada berbagai macam persoalan berbangsa dan bernegara yang bernuansa ancaman bagi demokrasi, sehingga sangat dibutuhkan alternatif untuk mengatasi hal tersebut. Untuk keluar dari masalah ini tepatlah kiranya apabila kita kembali bercermin pada masa lalu yang telah menggoreskan berbagai peristiwa penting yang di dalamnya penuh dengan muatan hikmah. Dari uraian tersebut maka permasalahan terpusat pada kemajuan-kemajuan yang dialami kerajaan Makassar pada abad XVII yang berorientasi pada kehidupan pluralistik.

Tujuan dari penulisan makalah ini berupaya mengungkapkan kemajuankemajuan kota Makassar pada abad ke XVII dengan tidak lepas dari kehidupan pluralistik dari komunitas Makassar. Dengan demikian nantinya diharapkan dapat bermanfaat untuk menambah khasanah pengetahuan kita mengenai eksistensi bangsa Indonesia dalam sejarah perjalanan bangsa. Khususnya kepada pemerintah Sulawesi Selatan, kiranya peristiwa abad XVII ini dapat dijadikan acuan dalam menata kehidupan masyarakat.

\section{B. Konsep Pluralistik}

Tuhan Yang Maha Esa menciptakan manusia dalam kondisi beragam, seluruh individu memiliki persamaan dan perbedaan baik dalam bentuk tubuh, warna kulit, sidik jari maupun dalam hal bahasa seperti getaran suara, kefasihan, kekerasan, kelembutan dan dalam dialeknya serta sifat pengucapannya. Dengan perbedaan 
keberagaman dan pluralitas dalam bahasa, bentuk tubuh dan warna kulit kemudian membentuk golongan, bangsa, bahasa serta peradaban dan agama yang berbeda-beda. Dalam memelihara hubungan antara perbedaan dan keberagaman tersebut, maka faktor kebersamaan akan mengikat masing-masing dimensi untuk menjadi satu kesatuan.

Sehubungan dengan hal tersebut di atas, maka konsep pluralitas dalam kehidupan ummat manusia diinterpretasikan sebagai keberagaman manusia seperti ras, suku, warna kulit, golongan, bangsa, bahasa maupun keberagaman agama. Dengan demikian pluralitas, keberagaman atau kemajemukan layaknya seperti pelangi yang memiliki warna beragam yang tidak dapat dipisahkan satu dengan lainnya.

Konsep lain mejelaskan bahwa pluralitas adalah kemajemukan yang didasari oleh keutamaan dan kekhasan. Karena itu pluralitas tidak dapat terwujud atau terbayangkan keberadaannya kecuali sebagai obyek komparatif dari keseragaman dan kesatuan yang merangkum seluruh dimensinya. Pluralitas tidak dapat disematkan kepada situasi cerai berai dan permusuhan yang tidak memiliki tali persatuan yang menghubungkan dan mengikat semua pihak

Islam sebagai agama yang diturunkan Allah untuk membawa rahmat bagi seluruh alam, menjelaskan tujuan Allah membentuk pluralitas. Islam tidak memandang pluralitas sebagai sebuah perpecahan yang membawa bencana. Islam memandang pluralitas sebagai rahmat bagi makhluk-Nya. Dengan pluralitas, kehidupan menjadi dinamis karena terdapat kompetisi dari masing-masing elemen untuk berbuat yang terbaik. Hal ini membuat hidup menjadi tidak membosankan karena selalu ada pembaruan menuju kemajuan.

Pluralisme agama bukanlah sinkretisme yakni menciptakan suatu agama baru dengan memadukan unsur-unsur tertentu atau sebagian komponen ajaran dari beberapa agama untuk dijadikan bagian integral dari agama tersebut. Seperti munculnya agama Bahaisme di Iran, yang didirikan pada pertengahan abad ke-I9. Sumber ajaran ini diambil dari agama Yahudi, Kristen dan Islam.

Pandangan pluralisme dianut oleh kaum Perennialisme yang berpandangan bahwa setiap agama telah mengandung kebenaran yang disebutnya inner metaphisical truth of religius (kebenaran metafisis batinia agama-agama), yang meingimplikasikan sikap keagamaan yang inklusif, tidak absolutisme dan eksklusif. Menurut Nurcholish Madjid pluralisme agama adalah semua agama yang benar adalah sama, karena samasama bersumber dari Tuhan. Semua Nabi dan Rasul membawa misi yang mengajarkan petunjuk Allah, karena itu ummat Islam harus mengakui kebenaran agama-agama lain.

\section{Pluralitas dan Kemajuan Makassar Abad Xvii}

Kerajaan Makassar yang mulai mengembangkan sayap kekuasaannya pada abad XVI di bawah pemerintahan raja Gowa ke IX Daeng Matanre Tumaparisi Kallonna sampai raja Gowa ke XV Sultan Al Malikussaid menjadikan Somba Opu sebagai Ibu Negeri Kerajaan. Masa pemerintahan Tumaparisi Kallonna merupakan awal dijumpainya catatan yang menceriterakan hal ihwal pemerintahannya, walaupun catatan itu hanya mengutarakan kejadian-kejadian penting secara kronologis belaka. 
Dari catatan itu diketahui bahwa pada masanya, kerajaan Gowa memulai usaha perluasan wilayah dan pengaruh kekuasaannya.

Perluasan kekuasaan dan wilayah kekuasaan yang dicanangkan oleh Tumaparisi Kallonna ini dilanjutkan oleh penggantinya Tunipallangga Ulaweng. Terhadap kerajaan yang ditaklukkan, Karaeng Tunipallangga Ulaweng mewajibkan raja-raja itu menyatakan ikrar tunduk dan patuh kepada nya -Makkanama numammiyo $=$ aku bertitah engkau mematuhi. Pada masanya hampir seluruh daerah yang berada di bagian selatan dikatakan telah tunduk dan patuh dibawah pemerintahannya.

Di samping usaha perluasan wilayah dan pengaruh kekuasaan untuk mencapai keunggulan kekuasaan, dikembangkan pula usaha-usaha di bidang pelayaran dan perdagangan. Dalam bidang perdagangan, Makassar mengalami kemajuan sehingga menempatkan Kota Makassar sebagai bandar niaga. Kemajuan pesat yang dialami oleh Makassar di bidang perdagangan ini dimungkinkan pula oleh jatuhnya Malaka ke tangan Portugis pada tahun 1511. Kejatuhan Malaka meniupkan angin baru bagi pengembangan kedudukan pelabuhan Makassar menjadi pelabuhan transito dan bandar niaga yang ramai dan menjadi pusat perdagangan rempah-rempah yang terpenting.

Pada permulaan abad ke tujuh belas, Makassar telah mendapat keunggulan kekuasaan dan keterlibatannya dalam bidang perdagangan menempatkan kerajaan ini sebagai satu kekuatan yang tangguh dan saingan yang besar dalam percaturan perdagangan. Hal ini didorong oleh peranan yang dimainkan oleh pelaut-pelaut Makassar dan Bugis dalam dunia pelayaran dan perdagangan rempah-rempah. Ini jelas dapat diketahui dari tulisan F. W. Stapel yang menyatakan: "Makassar termasuk tempat-tempat terpenting di kepulauan pada permulaan abad ke tujuh-belas, ibu kota dari kerajaan nama itu, juga disebut Gowa. Kota itu sendiri menyerahkan tidak lain dari pada "kelebihan" bahan-bahan kebutuhan hidup terutama beras, yang diusahakan di Sulawesi Selatan dalam jumlah besar. Pentingnya kota itu juga terutama karena kota itu sejak dahulu merupakan bandar niaga yang besar bagi rempah-rempah dari Maluku, yang dimasukan di sini oleh pelaut Bugis dan dibeli baik oleh orang-orang Portugis, yang memiliki kantor dagang di sana, maupun oleh pedagang-pedagang orang Hindia Muka"

Ketenaran dan kemajuan Makassar pada awal abad tujuh belas bukan hanya dalam hal kekuasaan dan perdagangan saja, akan tetapi Makassar dikenal pula sebagai pusat pengembangan Agama Islam di bagian timur nusantara.

Baik Lontara Pattorioloanga ri Tugowaya maupun Lontara Bilanga menyatakan bahwa pada tanggal 22 September 1605 bertepatan 9 Jumadil Awal 1014 H malam Jumat, Raja Tallo merangkap Mangkubumi kerajaan Gowa bernama I Malingkaang Daeng Manyonri Karaeng Tumenanga ri Bontobiraeng mula-mula menganut agama Islam. Kemudian disusul oleh Raja Gowa I Mangarangi Daeng Manrabbia. Raja Tallo diberi gelar Sultan Abdullah Awalul Islam dan Raja Gowa diberi gelar Sultan Alauddin. Hanya dalam waktu dua tahun (1607) rakyat Gowa Tallo pada umumnya memeluk agama Islam dan atas prakarsa raja Tallo yang dikenal dengan Karaeng Matowaya maka raja Gowa memaklumkan bahwa agama Islam 
adalah agama kerajaan di Gowa Tallo. Peng $\neg$ islaman seluruh Sulawesi Selatan dijalankan oleh kerajaan Gowa mulai tahun 1605-1612.

Terjadinya Islamisasi di awal abad XVII ini seiring dengan terjadinya perubahan dalam tatanan kehidupan masyarakat. Suasana dan semangat keagamaan terutama sekali setelah diterimanya Islam menjadi agama kerajaan mengutamakan persamaan antara sesama manusia. Dengan asas sipakatau dengan tata kelakuan yang terkendali oleh siri ( harga diri ) dan pacce ( kesetiakawanan ) serta persamaan hak yang tercipta dalam berinteraksi sesama manusia, maka masyarakat Makassar dengan mudah saling menghargai sekalipun berbeda agama, suku dan ras. Sehingga sikap toleransi dalam hidup bersama yang saling menghargai dapat dipelihara dalam berinteraksi, bermasyarakat dan berkehidupan bersama.

Sikap toleransi yang diperlihatkan oleh Sultan Alauddin pada masanya menimbulkan keinginan pedagang-pedagang asing dan pedagang lainnya untuk menetap di bandar Makassar termasuk pedagang dari Belanda. Akan tetapi Belanda bercita-cita untuk memonopoli perdagangan di Sulawesi Selatan utamanya di bandar Makassar, maka Sultan Alauddin menyikapi usaha tersebut dengan mengeluarkan deklarasi sebagai prinsip kebebasan yakni:"Godt heeft ende de see gemaekt, d'aerde onder de menscehen verdayltende de zee gemeyn gegeven. Noyt is gehoort, dat yemant de zeevaert verboden zij. Wilt ghij het doen, soo beneempt ghijde luyden het broot uyt de mont"

Tuhan telah menciptakan bumi dan lautan, dan telah membagikan bumi di antara manusia, begitupun Dia memberi lautan sebagai milik bersama. Tidak pernah kami mendengar bahwa di lautan dilarang bagi seseorang. Jika engkau melakukan larangan itu, berarti engkau seolah-olah mengambil roti dari mulut orang lain.

Pernyataan dari sumber lain, kalimatnya berbeda namun maksud dan tujuannya sama yang menyatakan bahwa : " Selama laut biru, semua orang sama kedudukannya di mata raja. Selama mereka mau berdagang, Makassar terbuka untuk siapa saja"

Jadi siapa saja boleh berusaha tanpa perbedaan. Kebijaksanaan yang sama, juga diterapkan oleh penguasa berikutnya yakni I Mannuntungi Daeng Mattola Karaeng Lakiung Sultan Malik As-Said sebagai raja Gowa Tallo XV dan raja Gowa Tallo XVII Mallombasi Daeng Mattawang Karaeng Bonto Mangape Sultan Hasanuddin. Sebagaimana yang dikemukakan oleh Pelras bahwa " Raja-raja Makassar secara kontinyu memperlihatkan sikap yang baik"

Prinsip laut bebas (mare leberum) yang diterapkan oleh raja-raja di abad XVII tersebut menyebabkan pedagang-pedagang dari daerah sekitar seperti Melayu, Jawa, Aceh dan Banjar serta pedagang-pedagang asing lainnya seperti Portugis, Inggris, Prancis, Cina, India, Denmark, Spanyol dan Arab semuanya datang silih berganti meramaikan pelabuhan bandar Makassar dan menjalin hubungan dagang. Bahkan mereka diberi izin menetap dan mendirikan gudang barang (loji) di sekitar bandar Makassar, sehingga puluhan kantor dagang orang asing dan pribumi berjejer di pantai barat. Dengan demikian Makassar menjadi kota plural dan menjadi salah satu gudang barang terbesar di Asia Tenggara. Makassar menjadi pusat perdagangan di Sulawesi Selatan yang bertaraf Internasional. Sebagaimana tercatat dalam tulisan Anthony Reid bahwa "Indonesia pernah mengalami perkembangan yang luar biasa di masa lalu. 
Meskipun dalam konteks ini perkembangan Makassar sangat luar biasa dan tidak terdapat pusat perdagangan di Sulawesi Selatan yang pernah ikut dalam taraf Internasional kecuali kerajaan Makassar "

Makassar dikenal pula atas kemampuannya bekerja sama dengan pembesarpembesar kerajaan yang terkemuka di Nusantara dan bekerja sama dengan penguasa kapitalisme di masa lalu, hal tersebut terlihat dari keberaniannya membela dan mempertahankan perinsip kebebasan dalam melawan cita-cita monopoli Belanda dan dalam proses selanjutnya menjadi salah satu kota perdagangan Asia. Semangat jiwa yang tak dapat ditawar bekerja sama dengan pedagang-pedagang Eropa, Cina dan pedagang-pedagang Asia Tenggara dalam upaya modernisasi.

Berkat kemampuan intelektual I Mangadacina Daeng Sitaba Karaeng Patingaloang yang menjabat sebagai raja Tallo dan sekaligus sebagai Mangkubumi kerajaan Gowa pada periode I Manuntungi Daeng Mattola Karaeng Lakiung Sultan Malikussaid raja Gowa XV (1639-1653) maka susunan ketatanegaraan semakin sempurna dan Makassar semakin berkembang menjadi kota dan bandar niaga dengan segala alat perlengkapannya. Makassar dilengkapi dengan benteng-benteng pertahanan utama yaitu Somba Opu, keraton raja yang megah di sebelah selatan dilindungi oleh benteng Panakukang dan di sebelah utara oleh benteng Ujung Pandang. Bahkan pada peta Kompeni perdagangan Belanda sekitar 1638 (koleksi Museum Kota Makassar) tampak bahwa istana raja dikelilingi oleh daerah-daerah pemukiman bangsa asing antara lain pemukiman orang Portugis, Gujarat, Denmark, Inggris dan saudagar-saudagar lainnya.

Hubungan persahabatan dengan kerajaan di Nusantara sebagai tindak lanjut dari jejak yang dilalui Sultan Alauddin seperti dengan Mataram, Banten, Aceh dan Maluku lebih diperkuat lagi dan mereka saling membantu jika salah satunya dalam kesulitan. Dengan kefasihahan Patingaloang yang menguasai berbagai bahasa, maka hubungan persahabatan yang erat terjalin pula dengan Gubernur Spanyol di Manila, Raja Muda Portugi Di Goa India, Presiden di Kelling, dengan Raja Inggris, Raja Portugis, Raja Kastilia (Spanyol) dan Mufti di Mekkah. Pada masa pemerintahannya, baginda menyelenggarakan delegasi kekuasaan kepada pembesar-pembesar dengan cermat, sehingga kedudukan Makassar sebagai ibu negeri kerajaan menjadi sangat terpandang dalam rangka pergolakan abad XVII di Nusantara ini.

Sekalipun politik pintu terbuka bisa dipandang sebagai tidak lebih dari kebutuhan perdagangan di Makassar, namun dalam sejarah menyebutkan bahwa tidak ada keraguan mengenai kemajuan Makassar. Makassar maju tidak hanya dalam bentuk perdagangan dan penaklukan terhadap daerah-daerah sekitarnya serta perkembangan dalam bentuk fisik kota Makassar, tapi juga dalam hal tekhnis dan intelektual. Seperti pada masa Tumaparisi Kallonna 1510-1546 sebagai peletak dasar pengembangan kerajaan Gowa yang mengawali sistem penulisan oleh Daeng Pamatte dan pengembangan administrasi pemerintahan serta awal mula diangkatnya syahbandar yang mengurus bea cukai bandar niaga. Kemudian raja ke X Tunipallangga Ulaweng memprakarsai penggunaan awal batu bata untuk mempermanenkan benteng utama, pembuatan serbuk mesiu, sistem berat dan skala.

Di antara tanda-tanda yang paling mengesankan pada abad XVII di Makassar adalah penerjemahan ke dalam bahasa Makassar mengenai keahlian dan tata cara 
membuat dan memakai meriam serta pembuatan peta. Dan yang paling unik lagi adalah catatan harian istana dalam hal politik dan peristiwa militer, yang ditulis sama rapihnya dengan catatan mengenai kelahiran, perkawinan dan kematian dalam lingkungan istana.

Politik pintu terbuka yang mewarnai kehidupan perdagangan Makassar pada masa itu berhasil melakukan kerjasama perdagangan sampai ke Asia Timur dan Tenggara. Dalam hubungan ini peranan pelaut dan pedagang Sulawesi Selatan tidak dapat diabaikan. Mereka melakukan pelayaran niaga antara Makassar dan daerah produksi komoditi terpenting ketika itu; rempah-rempah di Maluku dan kayu cempa di Tomor dan Sumba.

Untuk lebih memikat dan mempererat hubungan niaga, pemerintah memberikan peluang bagi para pendatang untuk mendirikan perwakilan dagang mereka sekalipun hubungan antar komunitas tersebut masing-masing diikat oleh perjanjian-perjanjian yang masing-masing harus mematuhi kewajiban mereka dan mengakui hak yang lain. Itulah sebabnya, sejak Tunipallangga Ulaweng diberitakan hanya ada perwakilan dagang Portugis, maka pada perkembangan kemudian dapat dicatat sejumlah perwakilan dagang bangsa asing lainnya, seperti Belanda pada 1607, Inggris pada 1613, Spanyol pada 1615, Denmark pada 1618, dan Cina pada 1618. Ia mengizinkan juga didirikan tempat ibadah bagi mereka, seperti untuk pedagang Melayu didirikan masjid pada masa pemerintahan I Mangorai Daeng Mammeta Karaeng Bontolangkasa (1565-1590) dan bagi mereka yang beragama Keristen; pada tahun 1640-an, yaitu pada masa pemerintahan I Mannutungi Daeng Mattola Karaeng Ujung Sultan Al Malikussaid (1639-1653) dinyatakan telah dibangun beberapa gereja.

Bukti-bukti sejarah ini menunjukkan bahwa dalam pergaulan hidup sehari-hari di Makassar pada masa itu memberikan indikasi terbentuknya masyarakat yang flural dan adanya toleransi antar ummat beragama, sehingga kebebasan untuk melaksanakan ajaran agama yang diyakini dapat terselenggara dengan baik. Makassar dapat membangun suatu tatanan kehidupan yang memberikan jaminan kesejahteraan dan kedamaian sekalipun akhirnya kehidupan tersebut tidak dapat dipertahankan.

\section{Penutup}

Pluralisme merupakan suatu paham dalam kehidupan sosial yang meyakini adanya perbedaan yang tidak bisa terhindarkan secara substantif. Pemahaman akan adanya kemajemukan ini akan berimplikasi pada timbulnya saling pengertian akan perbedaan tersebut. Sehingga setiap individu akan memberikan kesempatan kepada orang lain untuk berkembang tanpa mengusik atau membatasi ruang geraknya.

Realitas kehidupan yang seperti ini terwujud di Makassar pada abad ke XVII. Hal ini dibuktikan dengan terjalinnya komunikasi melalui suasana dialog antar ummat beragama, meningkatkanya toleransi antara ummat beragama, dan dibarengi dengan sikap pluralistik. Beberapa fakta pendukung dari adanya kehidupan plural di Makassar ini sebagai berikut:

Kesediaan masyarakat setempat menerima kedatangan bangsa asing untuk berdagang, walaupun di antara para pendatang memiliki latar belakang etnik budaya, dan agama yang berbeda. Ini juga terkandung makna bahwa sesungguhnya dalam kehidupan sosial, meluasnya pergaulan adalah peluang untuk kesuksesan dalam 
kehidupan perekonomian, sehingga perbedaan itu bukannya membawa mudharat, bahkan banyak membawa manfaat.

Agama yang dianut oleh masyarakat yang berbeda-beda bukanlah menjadi penghalang untuk terwujudnya kehidupan yang harmonis, apabila perbedaan ini tidak dijadikan sebagai dasar kebencian. Toleransi antar ummat beragama di Makassar dapat terwujud, salah satu faktor pendukungnya adalah karena dari pihak penguasa tidak mengadakan "keberpihakan" kepada salah satu agama, bahkan menjadi pasilitator untuk terjalinnya toleransi antar ummat beragama tersebut.

Kepentingan-kepentingan di luar agama, seperti kepentingan politik dan ekonomi tidak menjadi alasan bagi salah satu penganut agama untuk membenci penganut agama lain.

Berdasarkan uraian di atas, maka untuk menjadikan fakta sejarah di Makassar sebagai pelajaran dalam kehidupan berbangsa dan bernegara pada saat sekarang ini, paling tidak ada tiga langkah yang harus di tempuh untuk menghindari semakin meluasnya permusuhan antar ummat beragama yaitu; 1) menciptakan suasana dialog antar ummat beragama, 2) meningkatkan sikap toleransi antar ummat beragama, dan 3) adanya sikap pluralistik antar pemeluk agama.

\section{Daftar Pustaka}

Andaya, Leonard,Y. The Haritage of Arung Palakka: A History of South Sulawesi (Celebes) In the Seventeenth Century,(The Hague: Martinus Nijhoff), 1981

Darmawan, M.R. Bugis Makassar Masyarakat Terbuka dalam Yudistira Sukatanya, Makassar Doeloe, Makassar Kini, Makassar Nanti, (Makassar: Yayasan losari Makassar), 2000

Kadir, Ahmad, et al. Sejarah Daerah Sulawesi Selatan, Jakarta:Departemen Pendidikan dan Kebudayaan, 1978

Mahmud, Moh. Nasir. Epistemologi dan Studi Islam Kontemporer. Ujung Pandang: Bunga Rampai, 1999

Madjid, Nurcholis. Fluralitas Agama. Bandung: Mizan, 2002

Mattulada, Menyusuri Jejak Kehadiran Makassar Dalam Sejarah. Ujung Pandang: UNHAS, 1991

Muhammad, Imarah. Islam dan Fluralitas Perbedaan dan Kemajemukan dalam Bingkai Persatuan. Jakarta: Gema Insani Press, 1999

Patunru, Abd Razak. Sejarah Gowa. Makassar: Yayasan Kebudayaan Sulawesi Selatan, 1997

Pelras, Critian. Religion Tradition and the Dinamics of Islamization in South Sulawesi, Arcipel 
Reid, Anthony. t. th., The Rise of Makassar

Anthony Reid, Authority and Enterprise Among The Peoplpes of Sout h Sulawesi. Leiden; The Nederlands), 2000

Shihab, Alwi. Islam Inklusif. Mizan: Bandung, 1999

Stapel, F.W. Het Bongaais Verdrag: Disertasi. Leiden. Lerdsche Universitet, 2000

Wolhoff, GJ dan Abdurrahim, Sejarah Gowa: Yayasan Kebudayaan Sulawesi Selatan dan Tenggara. t. t. 